\title{
Efisiensi Kinerja Aparatur Sipil Negara dalam Sistem Work From Home
}

\section{Performance Efficiency of State Civil Servants in The Work From Home System}

\author{
Norma Parulian Saragi Napitu' ${ }^{1}$, Humaizi², \& Budi Hartono ${ }^{1}$
}

1Pascasarjana, Magister Administrasi Publik, Universitas Medan Area, Indonesia

2Pascasarjana, Magister Administrasi Publik, Universitas Sumatera Utara, Indonesia

Diterima: 10 Juni 2021; Disetujui: 15 Desember 2021; Dipublish: 01 Januari 2022

\begin{abstract}
Abstrak
Dalam rangka meminimalisasi penyebaran virus corona tipe baru atau SARS-CoV-2 penyebab covid-19, masyarakat diminta untuk bekerja, belajar dan beribadah dari rumah. kegiatan tatap muka untuk di tunda atau dibatalkan. work from home memiliki kewajiban dan tanggung jawab yang sama dengan bekerja dari kantor. work from home memiliki tantangan dan kendala yang tidak mudah, karena tidak semua sektor pekerjaan dapat dikerjakan dari rumah. Tujuan penelitian untuk mengetahui dan menganalisa efisiensi kinerja dan untuk mengetahui faktor-faktor penghambat efisiensi kinerja Aparatur Sipil Negara dalam sistem Work From Home di lingkungan Kantor Regional VI Badan Kepegawaian Negara Medan. dengan metode kualitatif, teknik analisis data menggunakan penelitian deskriptif. Hasil penelitian menunjukkan selama WFH biaya pengeluaran kantor berkurang mencapai $40 \%$ setiap bulannya, Pegawai yang wajib di WFH kan adalah yang menggunakan kendaraan umum dan berusia diatas 50 tahun, namun tidak menutup kemungkinan usia dibawah 50 tetap dapat di WFH kan, kondisi sakit. Faktor penghambat dalam melaksanakan WFH adalah tidak tersedianya fasilitas sarana dan prasarana seperti laptop / Komputer, Printer serta paket data internet, Gangguan dari anggota keluarga, menunda-nunda pekerjaan, mendahulukan pekerjaan dirumah dibandingkan pekerjaan kantor. Disarankan agar pegawai selama WFH membuat ruang khusus, list pekerjaan, batasan waktu, komunikasi rutin dengan atasan.
\end{abstract}

Kata Kunci: Efisiensi Kinerja; Aparatur Sipil Negara; Work from Home.

\section{Abstract}

In order to minimize the spread of the new type of corona virus or SARS-CoV-2 which causes covid-19, people are asked to work, study and worship from home. face-to-face activities to be postponed or canceled. work from home has the same obligations and responsibilities as working from the office. work from home has challenges and obstacles that are not easy, because not all sectors of work can be done from home. The research objective was to determine and analyze the efficiency of performance and to determine the factors inhibiting the efficiency of the performance of the State Civil Apparatus in the Work from Home system in the Regional Office VI of the Medan State Civil Service Agency. with qualitative methods, data analysis techniques using descriptive research. The results showed that during WFH the cost of office expenses was reduced by $40 \%$ each month, the employees who are obliged to be in WFH are those who use public transportation and are over 50 years old, but it does not rule out the possibility that the age below 50 can still be in WFH, sick condition. Inhibiting factors in implementing WFH are the unavailability of facilities and infrastructure such as laptops / computers, printers and internet data packages, interference from family members, procrastinating work, prioritizing work at home compared to office work. It is recommended that employees during WFH create a special room, list of jobs, time limits, and communicate regularly with superiors.

Keywords: Performance Efficiency; State Civil Apparatus; Work from Home.

How to cite: Napitu, N.P.S. Humaizi. \& Hartono, B. (2022). Efisiensi Kinerja Aparatur Sipil Negara Dalam Sistem Work From Home. PERSPEKTIF, 11 (1): 179-186.

*Corresponding author:

E-mail: budihartono@staff.uma.ac.id ISSN 2085-0328 (Print) ISSN 2541-5913 (online) 


\section{PENDAHULUAN}

Bekerja dari rumah atau work from home yang dilaksanakan saat ini merupakan tindak lanjut atas himbauan Presiden Joko Widodo pada Konferensi pers di Istana Bogor Jawa Barat tanggal 15 Maret 2020. Presiden menghimbau agar dapat meminimalisasi penyebaran virus corona tipe baru atau SARSCoV-2 penyebab covid-19, masyarakat diminta untuk bekerja, belajar dan beribadah dari rumah, salah satu menciptakan sistem bekerja dari rumah. Himbauan ini khususnya untuk Aparatur Sipil Negara, telah ditindaklanjuti oleh Menteri Pendayagunaan Aparatur Sipil Negara dan Reformasi Birokrasi melalui Surat Edaran Nomor 19 Tahun 2020 tentang penyesuaian sistem kerja Aparatur Sipil Negara dalam upaya pencegahan Covid-19 di lingkungan Instansi Pemerintah. Disebutkan bahwa Aparatur Sipil Negara dapat bekerja di rumah / tempat tinggal, tetapi dipastikan ada dua level pejabat struktural tertinggi yang bekerja di kantor. Selain itu ada larangan kegiatan tatap muka yang menghadirkan banyak peserta untuk di tunda atau dibatalkan. Menyikapi situasi dan informasi yang terus berkembang terkait penyebaran Covid-19.

Badan Kepegawaian Negara telah mengambil berbagai kebijakan diantaranya dengan mengeluarkan surat edaran yang berisi kebijakan bekerja dari rumah atau work from home bagi para Pegawai Kantor Regional VI Badan Kepegawaian Negara Medan. Kantor Regional VI Badan Kepegawaian Negara Medan mulai melaksanakan Work from Home sejak tanggal 23 Maret 2020 sampai dengan 30 Nopember 2020, kondisi tersebut mengacu pada Surat Edaran Nomor 3/SE/III/2020 tentang perubahan atas surat edaran Kepala Badan Kepegawaian Negara Nomor 2/SE/III/2020 tentang pencegahan penyebaran Corona Virus Disease (Covid-19) bagi pegawai di lingkungan Badan Kepegawaian Negara pada point 1 bagian 2 disebutkan pegawai yang tidak terlibat dalam kegiatan perkantoran sebagaimana tersebut pada angka 1 diwajibkan untuk bekerja di rumah dan tidak melakukan kegiatan di luar rumah. Di tindaklanjuti dengan Memo Dinas Kepala Kantor Regional VI Badan Kepegawaian Negara Medan Nomor 221/MD/KR.VI/BKN/III/2020 perihal jadwal kehadiran pegawai dalam rangka pencegahan penyebaran Covid-19 tanggal 23 Maret 2020.
Bekerja dari rumah atau work from home tentunya memiliki kewajiban dan tanggung jawab yang sama dengan bekerja dari kantor. Namun pada pelaksanaannya, penerapan work from home ternyata memiliki tantangan dan kendala yang tidak mudah, karena tidak semua sektor pekerjaan dapat dikerjakan dari rumah diantaranya kurang efektif nya komunikasi antara pimpinan dan bawahan, Jika melihat dari sisi pelayanan masyarakat dibidang kesehatan sangat tidak memungkinkan untuk bekerja dirumah karena profesi perawat, bidan dan dokter melakukan tindakan harus bertatap muka dengan pasien. Juga kegiatan dibidang kebutuhan bahan pokok dan bahan bakar minyak tidak dapat dilakukan dengan bekerja dari rumah. Namun disini peneliti hanya membatasi penelitian ini pada ruang lingkup Kantor Regional VI Badan Kepegawaian Medan saja. Banyak faktor yang dapat mempengaruhi pelaksanaan work from home seperti ketiadaan alat kerja dan komunikasi, kurangnya koordinasi, gangguan lingkungan di rumah tangga dan lain sebagainya.

Dalam penelitian ini peneliti menjabarkan kinerja Aparatur Sipil Negara dapat efisien dalam melaksanakan tugas dan fungsi masing-masing dengan adanya sistem Work From Home yang harus mengikuti protokol kesehatan. Dalam pengendalian pelaksanaan pekerjaan Kantor Regional VI Badan Kepegawaian Negara Medan memiliki berbagai perangkat berupa aplikasi yang berbasis online seperti: Aplikasi SAPK (Sistem Aplikasi Pelayanan Kepegawaian) digunakan dalam berbagai proses layanan kepegawaian seperti penetapan NIP, pencetakan surat keputusan pengangkatan CPNS, pemberian nota persetujuan/pertimbangan teknis kenaikan pangkat, penetapan dan pencetakan surat keputusan pemberhentian dengan hak pensiun dan updating data mutasi. (https://sapk.bkn.go.id); Aplikasi SAPK ini dapat digunakan dimana dan kapan saja melalui laptop atau computer sepanjang memiliki jaringan internet. Ketika melakukan pekerjaan ini di rumah masih memungkinkan untuk dapat dilaksanakan; Aplikasi E-Kinerja (Mengukur dan memantau kinerja Aparatur Sipil Negara secara periodik. Sebagai salah satu data acuan pemberian tunjangan kinerja yang diterima pegawai. (E-kinerjatunkin.bkn.go.id); Aplikasi e-kinerja inipun sama halnya dengan aplikasi SAPK dapat 
dilaksanakan dirumah sepanjang memiliki jaringan internet; Aplikasi LBP (location Based Presence) untuk memantau kehadiran setiap pegawai; Aplikasi LBP adalah absensi online pegawai berdasarkan lokasi dan jarak posisi dimana pegawai tersebut absen. Aplikasi ini dapat diunduh pada play store di handphone masing-masing pegawai

Namun, dengan adanya kebijakan work from home terdapat beberapa yang seharusnya dilaksanakan secara fisik tidak dapat dilaksanakan, seperti pemeriksaan kelengkapan berkas penetapan NIP dan penandatangan berkas-berkas penting lainnya, pemantauan kode etik kehadiran pegawai pada jam kerja.

Meskipun demikian, terdapat hal-hal lain yang memudahkan Kantor Regional VI Badan Kepegawaian Negara Medan dalam melaksanakan pemantauan pengendalian kehadiran saat ini, antara lain adalah dengan telah dilaksanakannya Aplikasi LBP (location Based Presence) untuk memantau kehadiran setiap pegawai yang mewajibkan pegawai untuk mengisi daftar hadir masuk dan pulang secara online. Dengan adanya fasilitas ini, tingkat kepatuhan pegawai dalam melaksanakan tugas secara work from home dapat dimonitor sesuai ketentuan yang berlaku.

Hanya saja tidak menutup kemungkinan ada kecurangan oknum pegawai yang melanggar aturan tersebut, salah satu contoh ketika yang bersangkutan work from home seharusnya yang bersangkutan absen tepat pada alamat rumah yang tercantum pada data kepegawaian, sementara oknum tersebut absen online bukan pada alamat rumah yang sudah ditetapkan.

Agar dapat menjalankan fungsi secara optimal dalam pelaksanaan work from home, Kantor Regional VI Badan Kepegawaian Negara Medan dalam hal ini Bagian Umum untuk memastikan hal-hal sebagai berikut: Melakukan identifikasi, siapa saja yang memungkinkan bekerja dari rumah, pekerjaan apa saja yang mungkin bisa dikerjakan dari rumah

Menentukan sumber daya peralatan yang dimiliki oleh pegawai, apakah pegawai mempunyai peralatan untuk bekerja di rumah, seperti laptop, dan apakah sambungan internetnya lancar, dsb; Menentukan bagaimana pengawasan dan koordinasi dilakukan (koordinasi pembagian tugas);
Memastikan pekerja dapat menggunakan perangkat/aplikasi untuk melakukan koordinasi jarak jauh dengan berbagai macam aplikasi yang telah tersedia; Mengadakan rapat intern dan extern yang dilaksanakan secara online melalui aplikasi zoom meeting.

Untuk dapat mewujudkan work from home yang produktif, diperlukan komunikasi dan kerjasama yang baik dari seluruh pihak, khususnya atasan dan bawahan, agar dapat meminimalisir faktor-faktor kendala yang mungkin terjadi. Dengan mengusung niat dan tujuan yang sama, yaitu memutus rantai penyebaran Covid-19, pelaksanaan work from home diharapkan tidak mengurangi tercapainya target kinerja yang telah diamanatkan oleh organisasi. Bagian umum yang bertanggung jawab penuh untuk menjalankan seluruh kebijakan organisasi dengan menjalankan pengendalian intern secara terus menerus dalam seluruh tahapan kegiatan.

Berdasarkan penjelasan di atas maka peneliti tertarik untuk meneliti lebih dalam mengenai efisiensi kinerja Aparatur Sipil Negara dalam sistem Work From Home di lingkungan Kantor Regional VI Badan Kepegawaian Negara Medan.

\section{METODE PENELITIAN}

Dalam penelitian ini, peneliti menggunakan metodologi penelitian deskriptif kualitatif Menurut Sukmadinata (2009) penelitian kualitatif adalah penelitian yang digunakan untuk mendeskripsikan dan menganalisa fenomena, peristiwa, aktivitas sosial, sikap, kepercayaan, persepsi dan orang secara individual maupun kelompok., Penelitian ini akan membahas Efisiensi Kinerja Aparatur Sipil Negara Dalam Sistem Work From Home dengan menggunakan teori yang disampaikan Timbal dan Mustabsat (2016) dalam Kathleen (2017) bahwa indikator dari efisiensi kinerja ASN dalam sistem Work From Home akan berhasil atau gagal dalam pelaksanaannya dengan membuat suatu komitmen bagi ASN dan kebijakan yang akan dilaksanakan selama WFH. Sumber data dalam penelitian ini adalah dengan mengumpulkan data primer dan data sekunder. Teknik yang di lakukan dalam proses pengumpulan data adalah observasi, dokumentasi dan wawancara. 
Indikator Work from home yang dikemukakan teori Timbal dan Mustabsat (2016) dalam Kathleen (2017) mencakup 7 (tujuh) variabel yaitu : lingkungan kerja flexibel, gangguan stress, kedekatan dengan keluarga, waktu perjalanan, kesehatan dan keseimbangan kerja, kreativitas dan produktivitas tinggi dan memisahkan pekerjaan rumah dan kantor agar terhindar dari tekanan diri. Yang mempengaruhi baik tidaknya dilaksanakan work from home. Oleh sebab itu peneliti akan melakukan analisa dari hasil penelitian yang akan dilakukan seperti disajikan. Data yang diperoleh baik dari kegiatan observasi, wawancara dan dokumentasi yang akan disampaikan dengan teknik analisis kualitatif dengan metode deskriptif bertumpu pada informasi yang didapat sesuai dengan rumusan masalah dalam penelitian ini.

\section{HASIL DAN PEMBAHASAN}

Efisiensi kinerja Aparatur Sipil Negara dalam sistem Work From Home di lingkungan Kantor Regional VI Badan Kepegawaian Negara Medan

Kebijakan work from home bagi pegawai Kantor Regional VI Badan Kepegawaian Negara Medan disambut dengan berbagai reaksi, ada yang menyambut dengan positif ada juga yang menyambut dengan negatif apakah Work From Home bisa digunakan dengan efisien, mengingat penerapannya diakibatkan karena adanya pandemi Covid-19 dengan kondisi sekarang ini mengharuskan semua aspek menerapkan "social distancing" dalam hal ini dengan kurangnya sarana dan prasarana yang digunakan untuk bekerja di rumah yang menjadi pemicu permasalahan utama dari penelitian ini. Tulisan ini akan membahas lebih lanjut tentang konsep Work From Home serta bagaimana hasil dari bekerja di rumah apakah berjalan dengan efisien atau sebaliknya tidak mengurangi kinerja pegawai.

Efisiensi Kinerja terhadap lingkungan kerja fleksibel. Berdasarkan hasil observasi dilapangan bahwa terkadang lingkungan kerja yang flexible pun tetap mempengaruhi efisiensi kerja pegawai, dimana ketika melakukan pekerjaan dari rumah pegawai harus membuat ruang khusus untuk bekerja yang nyaman dirumah agar tidak terganggu dengan lingkungan sekitar. namun demikian dengan adanya peraturan pemerintah setiap pegawai harus dapat dan mampu mengkondisikan dimanapun dan kapanpun pegawai tersebut melaksanakan pekerjaannya agar dapat memenuhi kinerja dari tiap-tiap pegawai.

Berdasarkan hasil wawancara dengan informan (P1) yaitu Kepala Bagian Tata Usaha Kantor Regional VI Badan Kepegawaian Negara Medan adalah sebagai berikut:

"Bahwa berdasarkan Peraturan yang diberlakukan pada Kantor Regional VI Badan Kepegawaian Negara bahwa 90 persen pegawai yang melaksanakan work from home dan 10 persen pegawai yang melaksanakan work from office, terkait dengan efisiensi kinerja ada beberapa yang berubah antara lain:

Dari sisi penganggaran untuk pembayaran rekening listrik terdapat penurunan pembayaran mencapai kurang lebih 40 persen dari pembayaran sebelumnya ketika dilaksanakan work from home dan begitu juga dengan rekening air mengalami penurunan rekening pembayaran.

Ada beberapa pekerjaan yang tidak dapat di lakukan ketika work from home misalnya pegawai yang menjabat pengelolaan barang milik negara dan pegawai yang menjabat pengadaan barang dan jasa.

Pegawai yang dapat di work from home kan adalah pegawai yang menjabat pengelola administrasi keuangan, petugas pengelola kehadiran, pegawai yang memakai kendaraan umum dan pegawai yang berusia diatas 50 tahun".

Hasil wawancara terkait bagaimana pengaruh lingkungan kerja dengan informan lain (P6) yaitu Pengolah Data Kepegawaian Kantor Kantor Regional VI Badan Kepegawaian Negara adalah sebagai berikut:

"Dengan sistem work from home yang diterapkan di lingkungan Kantor Regional VI BKN Medan tidak mempengaruhi efisiensi kinerja ASN karena dominan pekerjaan dikantor sudah berbasis digital elektronik, sehingga memudahkan pegawai untuk tetap bekerja di rumah dan tidak menghambat pekerjaan, sehingga ketika dilibatkan dengan efisiensi kinerja selama bekerja dari rumah tetap dapat dikerjakan, namun sarana dan prasarana yang diperlukan mungkin yang harus di persiapkan dari kantor". (Wawancara tanggal 22 April 2021).

Efisiensi kinerja terkait gangguan stress yang diakibatkan perubahan lingkungan. Berdasarkan hasil observasi 
dilapangan, bahwa dengan bekerja dari rumah sebagian pegawai ada yang mengalami gangguan stress namun ada juga pegawai yang senang dengan bekerja dari rumah, bagi pegawai yang mengalami gangguan stress jika tidak ditangani dengan baik maka menimbulkan kecemasan yang berkepanjangan dan depresi maka akan berujung kepada gangguan kesehatan mental

Hasil wawancara efisiensi gangguan stress dengan informan P1 Kepala Bagian Tata Usaha Kantor Regional VI Badan Kepegawaian Negara Medan adalah sebagai berikut:

"Terkadang ada sebagian pegawai mengalami hal perubahan psikis terhadap perubahan lingkungan kerja, namun ada juga yang tidak mengalami hal tersebut"

Hasil wawancara efisiensi gangguan stress dengan informan P3 yaitu Analis Kepegawaian Kantor Regional VI Badan Kepegawaian Negara Medan adalah sebagai berikut:

"Dengan bekerja dari rumah bisa memicu stress, karena pekerjaan rumah menyatu dengan pekerjaan dikantor, sementara target kerja harus terpenuhi setiap harinya".

Efisiensi kinerja terkait peran kedekatan dengan keluarga. Berdasarkan hasil observasi dilapangan, bahwa dengan bekerja dari rumah peran serta kedekatan dengan keluarga adalah faktor yang sangat penting dalam menunjang terlaksananya semua kegiatan yang dilaksanakan di dalam rumah, dimana adanya pembagian pekerjaan antar anggota keluarga lainnya, ini adalah penunjang yang sangat berperan untuk menyukseskan pekerjaan yang dibawa kerumah.

Hasil wawancara dengan informan (P1) yaitu Kepala Bagian Tata Usaha Kantor Regional VI Badan Kepegawaian Negara Medan adalah sebagai berikut:

"Peranan keluarga sangat penting ketika pegawai tersebut menjalankan work from home seperti membagi waktu bersama dengan suami, istri dan anak bagi yang sudah berkeluarga, Pegawai yang bekerja dari rumah tetap harus menyelesaikan pekerjaan rumah, contoh pegawai wanita harus bisa menyelesaikan pekerjaan mengurus anak, suami dan pekerjaan lainnya".

Hasil wawancara dengan informan P2 Kepala Bidang Status dan Kepegawaian Kantor
Regional VI Badan Kepegawaian Negara Medan adalah sebagai berikut:

"Dukungan keluarga sangat penting terutama dari segi peralatan, sarana dan prasarana yang dirumah, ruang kerja yang cocok dan tepat agar tidak terganggu tempat sarana dan prasarana tersebut ditempatkan".

Efisiensi kinerja terkait waktu perjalanan. Berdasarkan hasil observasi dilapangan, bahwa waktu perjalanan bagi pegawai yang jarak rumah dengan kantor memerlukan waktu yang lama untuk tiba dikantor adalah faktor yang mempengaruhi dibandingkan dengan pegawai yang bekerja dari rumah, hal ini juga dapat meningkatkan efisiensi kinerja pegawai apabila pegawai tersebut melaksanakan work from home.

Hasil wawancara dengan informan P2 Kepala Bidang Status dan Kepegawaian Kantor Regional VI Badan Kepegawaian Negara Medan adalah sebagai berikut:

"Pegawai yang menggunakan angkutan umum atau jarak dari rumah ke kantor jauh, sangat berpengaruh karena waktu dijalan, menghadapi macet, terutama penghematan biaya operasional diperjalanan (ongkos), penghematan waktu, karena waktu dapat membuat efisien dan tidak nya seseorang melaksanakan pekerjaanya, yang biasanya berangkat jam 7 dikarenakan WFH tidak perlu lagi bersiap-siap untuk berangkat ke kantor, waktu untuk berangkat kekantor sudah dapat dimanfaatkan oleh pegawai tersebut melakukan pekerjaan nya dari rumah, namun demikian target pekerjaan yang telah ditentukan dari kantor tetap dapat dikerjakan dengan baik dan harus tercapai, bahkan terkadang target yang dihasilkan ketika bekerja dari rumah lebih banyak daripada bekerja dikantor".

Hasil wawancara dengan informan (P3) yaitu Analis Kepegawaian Kantor Regional VI Badan Kepegawaian Negara Medan adalah sebagai berikut:

"Sangat berpengaruh karena pekerjaan akan lebih cepat selesai dikerjakan dari rumah, sementara jika bekerja dikantor akan menyita waktu dalam perjalanan, disamping macet dan kejadian-kejadian diluar dugaan akan menyita waktu".

Efisiensi kinerja terkait kesehatan dan keseimbangan kerja. Berdasarkan hasil observasi dilapangan, bahwa kesehatan dan keseimbangan kerja adalah hal yang perlu dijaga untuk menunjang tingkat efisiensi kerja 
seseorang, jadwal dan rencana kerja diatur sedemikian rupa dan waktu istirahat haruslah seimbang.

Hasil wawancara dengan informan P2 Kepala Bidang Status dan Kepegawaian Kantor Regional VI Badan Kepegawaian Negara Medan adalah sebagai berikut:

"Seseorang yang bekerja dari rumah tentu sangat dapat menjaga kesehatan dan keseimbangan kerja karena bekerja dari rumah pegawai tersebut lebih santai, ketika lelah dapat beristirahat sebelum melakukan aktivitas selanjutnya disamping waktu dari rumah lebih lama dibandingkan pegawai tersebut melaksanakan pekerjaan tersebut dikantor, ketika pegawai tersebut bekerja dari rumah lebih efisien daripada bekerja dikantor".

Hasil wawancara dengan informan (P5) yaitu Arsiparis Kantor Regional VI Badan Kepegawaian Negara Medan adalah sebagai berikut :

"Dengan adanya WFH dapat mendukung efiiensi kinerja pegawai karena kondisi kesehatan semakin terjamin dan baik, sehingga hasil kerja pegawai semakin maksimal, untuk laporan kinerja dapat dilakukan dengan aplikasi media elektronik yang telah tersedia".

Efisiensi kinerja terkait Kreativitas dan produktivitas tinggi. Berdasarkan hasil observasi dilapangan, bahwa kreativitas dan produktivitas tinggi selama bekerja dari rumah adalah tantangan baru buat pegawai yang melaksanakan work from home, karena pegawai diharapkan dapat berpikir kreatif dalam kesulitan yang ditemukan sehingga menghasilkan pemecahan masalah yang baik dan bekerja produktif saat bekerja dari rumah dan ini salah satu pilihan yang sangat cerdas adalah hal yang perlu dijaga untuk menunjang tingkat efisiensi kerja seseorang.

Hasil wawancara dengan informan (P4) yaitu Pengadministrasi Kepegawaian Kantor Regional VI Badan Kepegawaian Negara Medan adalah sebagai berikut:

"Kreatifitas perlu dikembangkan dari setiap pegawai dengan memberikan pelatihanpelatihan atau pengembangan diri sehingga pola pikir pegawai tersebut lebih terbuka untuk dapat melahirkan inovasi, kreativitas dalam mengatasi permasalahan dalam pekerjaan sehari-hari".

Hasil wawancara dengan informan P6 Pengolah Data Kepegawaian Kantor Regional VI
Badan Kepegawaian Negara Medan adalah sebagai berikut:

"Cara untuk mengembangkan potensi kreativitas pegawai selama menjalankan WFH adalah bekerja ditempat yang menghasilkan banyak inspirasi, istirahat yang teratur, meneladani orang yang memiliki kreativitas tinggi serta pantang menyerah untuk menemukan hal-hal baru".

Efisiensi kinerja terkait pekerjaan rumah dan kantor serta tekanan diri. Berdasarkan hasil observasi dilapangan, bahwa pegawai harus dapat memisahkan mana pekerjaan rumah dan mana pekerjaan kantor, kedua hal tersebut haruslah benar-benar dipisahkan, sehingga waktu yang digunakan pun tetap konsisten dalam pelaksanaannya, karena ketika dua hal ini dicampur aduk akan menimbulkan tekanan diri pada pegawai tersebut

Hasil wawancara dengan informan (P3) yaitu Analis Kepegawaian Kantor Regional VI Badan Kepegawaian Negara Medan adalah sebagai berikut:

"Agar dapat memisahkan pekerjaan rumah dan kantor serta tekanan diri, pegawai yang bersangkutan membuat jadwal atau membagi waktu yang sudah disepakati antara pekerjaan rumah dan pekerjaan kantor untuk menghindari tekanan dalam diri sendiri, sehingga pekerjaan kantor dan rumah dapat terselesaikan dengan sempurna". Apabila waktu tersebut sudah dapat dipergunakan dengan baik tekanan diri pada pegawai tersebut tidak akan terjadi".

Hasil wawancara dengan informan (P4) yaitu Pengadministrasi Kepegawaian Kantor Regional VI Badan Kepegawaian Negara Medan adalah sebagai berikut:

"Pegawai tersebut harus dapat menfokuskan diri kepada suatu objek kegiatan atau pekerjaan dengan mengesampingkan permasalahan keluarga dan tekanan dalam diri pegawai tersebut".

\section{Faktor-Faktor Penghambat Efisiensi Kinerja Ketika Bekerja Dari Rumah?}

Berdasarkan hasil observasi dilapangan, bahwa Faktor-faktor penghambat efisiensi kinerja ketika bekerja dari rumah adalah tidak tersedianya sarana dan prasarana seperti ketika pegawai bekerja dikantor, sarana prasarana dimaksud seperti computer/laptop, printer, paket data atau wifi, juga ketenangan 
bekerja ketika pegawai melaksanakan work from home.

Hasil wawancara dengan informan (P1) yaitu Kepala Bagian Tata Usaha Kantor Regional VI Badan Kepegawaian Negara Medan adalah sebagai berikut:

"Pada umumnya ketiadaan sarana prasarana seperti paket data, laptop, printer, tetapi ketika kantor tidak memfasilitasi sarana prasarana tersebut kepada pegawai yang WFH maka pegawai memilih tetap bekerja di kantor".

Hasil wawancara dengan informan (P5) yaitu Arsiparis Kantor Regional VI Badan Kepegawaian Negara Medan adalah sebagai berikut:

Menurut beliau hambatannya adalah sebagai berikut: Menunda-nunda pekerjaan, seperti mengulur waktu sehingga pekerjaan yang seharusnya segera diselesaikan menjadi tertunda; Terkadang timbul sifat malas untuk melaksanakan pekerjaan; Anggap remeh; Mendahulukan pekerjaan dari rumah dibandingkan pekerjaan kantor.

\section{SIMPULAN}

Efisiensi kinerja seorang pegawai ketika bekerja dirumah mempunyai 2 aspek yaitu kelebihan dan kekurangan nya masing-masing, bekerja dari rumah (work from home) memberikan suatu manfaat tersendiri kepada masing-masing pegawai dimana sebagaian besar pegawai menyatakan bahwa keunggulan utama dari konsep bekerja dari rumah ini adalah dari segi biaya yaitu pegawai dapat menghemat biaya transportasi menuju kantor sehingga hal ini dimanfaatkan untuk mengalihkan pengeluaran transportasi tersebut untuk memenuhi kebutuhan rumah tangga. Selain penghematan biaya transportasi hal lainnya adalah mengurangi tingkat stress mobilisasi karena kemacetan lalu lintas setiap harinya dalam melaksanakan aktivitas bekerja serta yang terpenting untuk kelebihan bekerja dari rumah pada masa pandemic Covid-19 ini adalah dapat mencegah penularan penyebaran virus Covid -19 karena secara langsung pegawai mengurangi interaksi dengan sesama rekan kerja secara fisik maupun interaksi secara sosial.

Hal lain yang menjadi penghambat bekerja dirumah bagi sebagian pegawai antara lain adalah: Tidak tersedianya fasilitas sarana dan prasarana seperti Laptop/Komputer, Printer serta paket data internet; Adanya gangguan ketika bekerja di rumah seperti gangguan dari anggota keluarga lainnya; Mengulur-ulur waktu sehingga pekerjaan tertunda; Malas dan anggap remeh; Mendahulukan pekerjaan dirumah dibandingkan pekerjaan kantor. Hal yang disarankan agar work from home tetap efisien dan tidak mengurangi kinerja pegawai adalah sebagai berikut: Membuat ruang khusus untuk bekerja dirumah agar tidak terganggu dengan lingkungan sekitar; Membuat list pekerjaan untuk esok harinya; Pastikan pekerjaan setiap hari selesai; Membuat batasan jam kerja yang jelas, antara pekerjaan rumah dengan pekerjaan kantor; Jika ada zoom meeting dari kantor, usahakan mengikutinya dengan baik; Gunakan waktu seefisien mungkin untuk menyelesaikan pekerjaan agar target kinerja terpenuhi; Tetap adakan komunikasi yang baik dan rutin kepada atasan; Mendisplinkan diri.

\section{DAFTAR PUSTAKA}

Anastacia, D., Nasution, I., \& Suharyanto, A. (2021). Peranan Motivasi dalam Meningkatkan Kinerja Pegawai Berbasis Kebutuhan. Strukturasi: Jurnal Ilmiah Magister Administrasi Publik, 3(2), 176-184. doi:https://doi.org/10.31289/strukturasi.v3 i2.747

Crosbie, T \& Moore, J. (2004). Work-Life Balance And Working From Home. Teesside University.

Farrell, K. (2017). Working From Home: A Double Edged Sword . Royal Society Of Medicine, 126.

Hamidi, (2007), Metode Penelitian dan Teori Komunikasi pendekatan Praktis Penulisan Proposal dan Laporan Penelitian, UMM Press, Malang, 2007.

Keputusan Menteri Kesehatan Republik Nomor HK.01.07/MENKES/413/2020 Tentang Pedoman Pencegahan Dan Pengendalian Corona Virus Disease 2019 (Covid-19) Tanggal 13 Juli 2020.

Keputusan Presiden Republik Indonesia Nomor 11 Tahun 2020 Tentang Penetapan Kedaruratan Kesehatan Masyarakat Corona Virus Disease 2019 (Covid- 19) Tanggal 31 Maret 2020.

Keputusan Presiden Republik Indonesia Nomor 12 Tahun 2020 Tentang Penetapan Bencana Non Alam Penyebaran Corona Virus Disease 2019 (Covid-19) Sebagai Bencana Nasional Tanggal 13 April 2020.

Keputusan Presiden Republik Indonesia Nomor 7 Tahun 2020 Tentang Gugus Tugas Percepatan Penanganan Corona Virus Disease (Covid-19) Tanggal 13 Maret 2020. 
Norma Parulian Saragi Napitu, Humaizi, \& Budi Hartono, Efisiensi Kinerja Aparatur Sipil Negara Dalam

Keputusan presiden, Peraturan pemerintah, Surat Edaran

Larson, B. (2020). Companies Can Help Employees Working Remotley During The Covid-19 Pandemic. Northeastern University Boston.

Latief, A. Rosalina, D. \& Apiska, D. (2019). Analisis Hubungan Antar Manusia terhadap Kinerja Karyawan. Journal of Education, Humaniora and Social Sciences (JEHSS). 1 (3): 127-131.

Moleong, L.J. (2006). Metodologi Penelitian Kualitatif. Edisi Revisi. Bandung: Remaja Rosdakarya.

Muslim, N. dan Irwan N., (2014). Kinerja Aparat Desa Dalam Penyelenggaraan Pemerintahan Di Desa Pantai Labu Pekan, JPPUMA: Jurnal Ilmu Pemerintahan dan Sosial Politik UMA (Journal of Governance and Political UMA), 2 (2): 114-124

Nawawi, H., dan Hadari, M.M. (1992). Instrumen Penelitian Bidang Sosial.Yogyakarta: Gadjah Mada University Press.

Novita, D., Kadir, A., \& Siregar, N. (2020). Analisis Kinerja Inspektorat Daerah Dalam Melakukan Fungsi Pengawasan (Studi Pada Inspektorat Kota Langsa). Strukturasi: Jurnal Ilmiah Magister Administrasi Publik, 2(2), 116-128.

doi:https://doi.org/10.31289/strukturasi.v2 i2.52

Peraturan Menteri Kesehatan Republik Indonesia Nomor 9 Tahun 2020 Tentang Pedoman Pembatasan Sosial Berskala Besar Dalam Rangka Percepatan Penanganan Corona Virus Disease 2019 (Covid-19) Tanggal 03 April 2020.

Peraturan Pemerintah Republik Indonesia Nomor 21 Tahun 2020 Tentang Pembatasan Sosial Berskala Besar Dalam Rangka Percepatan Penanganan Corona Virus Disease 2019 (Covid-19) Tanggal 31 Maret 2020.

Simbolon, A.H., dan Walid M.S., (2015). Evaluasi Kinerja Badan Permusyawaratan Desa dalam
Penyelenggaraan Pemerintahan Desa, JPPUMA: Jurnal Ilmu Pemerintahan dan Sosial Politik UMA (Journal of Governance and Political UMA), 1 (1): 143-159.

Sirait, N., Warjio, W., Harahap, D., \& Kadir, A. (2019). Analisis Kinerja Aparatur Sipil Negara dalam hal Disiplin Kerja di Kantor Kecamatan Tanjungbalai Utara Kota Tanjungbalai. Strukturasi: Jurnal Ilmiah Magister Administrasi Publik, 1(2), 165-175

Siregar, D. (2019). Pengaruh Motivasi dan Kompensasi terhadap Kinerja Karyawan pada Perseron Terbatas Digitdata Terminal Evolusi. Journal of Education, Humaniora and Social Sciences (JEHSS). 2 (1): 74 - 82.

Surat Edaran Menteri Pendayagunaan Aparatur Negara Dan Reformasi Birokrasi Nomor 54 Tahun 2020 Tentang Perubahan Ketiga Atas Surat Edaran Menteri Pendayagunaan Aparatur Negara Dan Reformasi Birokrasi Nomor 19 Tahun 2020 Tentang Penyesuaian Sistem Kerja Aparatur Sipil Negara Dalam Upaya Pencegahan Penyebaran Covid-19 Di Lingkungan Instansi Pemerintah Tanggal 12 Mei 2020.

Surat Edaran Menteri Pendayagunaan Aparatur Negara Dan Reformasi Birokrasi Nomor 55 Tahun 2020 Tentang Perubahan Atas Surat Edaran Menteri Pendayagunaan Aparatur Negara Dan Reformasi Birokrasi Nomor 46 Tahun 2020 Tentang Pembatasan Kegiatan Bepergian Ke Luar Daerah Dan/Atau Kegiatan Mudik Dan/Atau Cuti Bagi Aparatur Sipil Negara Dalam Upaya Pencegahan Penyebaran Covid-19 Tanggal 12 Mei 2020.

Tanjung, M., Kusmanto, H., Warjio, W., \& kadir, A. (2019). Evaluasi Kinerja Sekretariat Daerah Pemerintah Kabupaten Aceh Timur Tahun 2017. Strukturasi: Jurnal Ilmiah Magister Administrasi Publik, 1(1), 82-88. 